\title{
Coupling a hydrological water quality model and an economic optimization model to set up a cost-effective emission reduction scenario for nitrogen
}

\author{
Jan Cools ${ }^{a}, *$, Steven Broekx ${ }^{c}$, Veronique Vandenberghe ${ }^{a}$, Hannes Sels ${ }^{b}$, Erika Meynaerts ${ }^{c}$, \\ Peter Vercaemst ${ }^{c}$, Piet Seuntjens ${ }^{c, f, g}$, Stijn Van Hulle ${ }^{b}$, Hilde Wustenberghs ${ }^{e}$, Willy Bauwens ${ }^{d}$, \\ Marc Huygens ${ }^{a}$ \\ a SORESMA, Poortakkerstraat 41, B-9051 Ghent, Belgium \\ ${ }^{\mathrm{b}}$ Research Group EnBiChem, Department of Industrial Engineering and Technology, University College West Flanders, Ghent University Association, \\ Graaf Karel de Goede laan 5, B-8500 Kortrijk, Belgium \\ ${ }^{c}$ Flemish Institute for Technological Research (VITO), Boeretang 200, B-2400 Mol, Belgium \\ ${ }^{\mathrm{d}}$ Vrije Universiteit Brussel (VUB), Department of Hydrology, Faculty of Engineering Sciences, Pleinlaan 2, B-1050 Brussels, Belgium \\ e Institute for Agricultural and Fisheries Research (ILVO), Social Sciences Unit, Van Gansberghelaan 115 - box 2, B-9820 Merelbeke, Belgium \\ ${ }^{\mathrm{f}}$ Ghent University, Department of Soil Management, Coupure Links 653, 9000 Ghent, Belgium \\ ${ }^{\mathrm{g}}$ University of Antwerp, Faculty of Bioscience Engineering, Groenenborgerlaan 171, 2020 Antwerp, Belgium
}

\section{A R T I C L E I N F O}

\section{Article history:}

Received 5 October 2009

Received in revised form

21 April 2010

Accepted 22 April 2010

Available online 15 May 2010

Keywords:

River basin management

Water quality modelling

Costs

Nitrogen

Impact assessment

Cost-effectiveness

SWAT

\begin{abstract}
A B S T R A C T
A modelling approach is presented that determines the most cost-effective set of reduction measures to reach an in-stream concentration target. The framework is based on the coupling of two models: the hydrological water quality model SWAT and an economic optimization model (Environmental Costing Model, ECM). SWAT is used to determine the relationship between the modelled in-stream concentration at the river basin outlet and the associated emission reduction. The ECM is used to set up marginal abatement cost curves for nutrients and oxygen demanding substances. Results for nitrogen are presented for the Grote Nete river basin in Belgium for the year 2006.

Results show that the good status for total nitrogen can be reached in the study area. The most costeffective measures are more productive dairy cattle, implementing basic measures as defined in the WFD, winter cover crops, improved efficiency of WWTP, enhanced fodder efficiency for pigs, further treatment of industrial waste water and tuned fertilization.
\end{abstract}

(c) 2010 Elsevier Ltd. All rights reserved.

\section{Introduction}

The European Union Water Framework Directive (2000/60/EC), further abbreviated as WFD, requires member states, amongst others, to set up programs of cost-effective pollution abatement measures as part of the river basin management plans (RBMP). Consequently, in Europe, a shift is ongoing from classical methods such as 'trial and error' and 'worst polluter first' to an assessment of cost and impact of pollution abatement measures.

Yet, the assessment of the cost-effectiveness of emission reduction measures has been one of the bottlenecks in designing the RBMP's. Despite the simplicity of the concept of cost-effectiveness (e.g. explained in Brouwer and De Blois, 2008), the

\footnotetext{
* Corresponding author. Tel.: +32 9 2616338; fax: +32 92616301.

E-mail address: jan.cools@soresma.be (J. Cools).
}

availability of European Guidance documents (WATECO, 2002 and Interwies et al., 2004) and numerous publications on cost-effectiveness analysis for surface water quality improvements (e.g. Schleich and White, 1997; Lise and Van der Veeren, 2002; Tskhay et al., 2005; Arabi et al., 2006; Fröschl et al., 2008), the development of a cost-effective Programme of Measures for the RBMPs has not been straightforward. An important reason for this is the requirement for multi-scale and multi-disciplinary inputs from environmental scientists (effectiveness), economists (costs), engineers (technical details of measures) and river basin managers (targets and policy priorities). It becomes evident that this is a challenging task which needs support from appropriate information systems and modelling tools that are able to cope with the complexity of the water system and planning process (Hattermann and Kundzewicz, 2010). Despite their availability, modelling tools have only been used to a limited extent in many river basins for the development of the Programme of Measures. 
In Europe, several tools and methodologies have been developed that can be used by water authorities for planning and managing water resources in an integrated way at the scale of a river basin. Many of them have been integrated in the European 'Catchmod' project cluster (Hattermann and Kundzewicz, 2010). Turpin et al. (2005) and Volk et al. (2008) linked SWAT to an economic model for European watersheds. Similar hydrologic-economic modelling with SWAT is published in the US e.g. by Attwood et al. (2000), Gassman et al. (2002, 2006), Qiu (2005) and Arabi et al. (2006). Many authors furthermore published on the use of modelling and decision-support tools for river basin management among which Mysiak et al. (2005), Santhi et al. (2006), Holvoet et al. (2008), Gascuel-Odoux et al. (2009) and Schlüter et al. (2005). In a broader context, for natural resources management and biodiversity conservation, years of research has been done on tools for negotiation and cost-benefit analysis of management alternatives e.g. by Costanza et al. (1997), van Noordwijk et al. (2001), Balmford et al. (2002), Drechsler et al. (2007), Daily et al. (2009) and Nelson et al. (2009).

This paper presents a tool which is used for the development of the RBMP of the Scheldt river basin (Belgium). We present a generic framework which allows to determine the most costeffective set of reduction measures to reach an in-stream concentration target. The framework is based on a coupling of two models: the hydrological water quality model SWAT (Neitsch et al., 2005) and the Environmental Costing Model, abbreviated as ECM (Broekx et al., 2008).

The methodology discussed is used to assess the combined impact of measures on both point and diffuse sources and includes measures across sectors covering industry, agriculture, waste water treatment plants (WWTP) and households. Both the economic and hydrological model make use of the same emission databases and are built at the scale of a river basin. Especially for the economic model, this level of detail is contrary to most economic models, which usually follow administrative boundaries as countries or regions (Brouwer and Hofkes, 2008). This means up- or downscaling algorithms are not required since both models are built at the same scale and measures are defined on an individual source level. The databases have furthermore been negotiated and accepted by the competent authority.

The tool is developed for nitrogen, phosphorus and oxygen demanding substances. For the purpose of presenting the methodology this paper focuses on nitrogen pollution in a part of the Scheldt river basin, namely the Grote Nete river basin, in Belgium for the year 2006 .

\section{Methodology}

\subsection{The study area}

The watershed of the Grote Nete covers approximately $400 \mathrm{~km}^{2}$ and is situated in Flanders, the Northern region of Belgium as shown in Fig. 1. It is a typical lowland area with slopes of the river bed below $2 \%$. The dominant soil type is sand, with patches of loamy alluvial sediments. Average precipitation ranges from ca. 740 to $800 \mathrm{~mm} / \mathrm{y}$. The river basin is used intensively, having a high population density (200 inhabitants $/ \mathrm{km}^{2}$ ), high livestock density (average values are $150 \mathrm{cows} / \mathrm{km}^{2}$, $300 \mathrm{pigs} / \mathrm{km}^{2}$ and 4000 chickens $/ \mathrm{km}^{2}$ ) and intensive industry. About $60 \%$ of the total area is used for agriculture, mainly dairy and fodder production (pasture and corn land uses). Although large investments are made in order to improve the surface water quality, environmental pressures remain high and originate from all sectors. In 2006, approximately $30 \%$ of the study areas inhabitants were not connected to a waste water treatment plant and discharge directly into surface water. These households contribute $23 \%$ of the nitrogen emission loads. The agricultural sector used in average $220 \mathrm{kgN} / \mathrm{ha}$ of fertilizer, of which $81 \%$ is animal manure and $19 \%$ artificial fertilizer and cause $35 \%$ of the nitrogen emission loads. Industry and waste water treatment plants contribute respectively $15 \%$ and $26 \%$ of the nitrogen emission load.

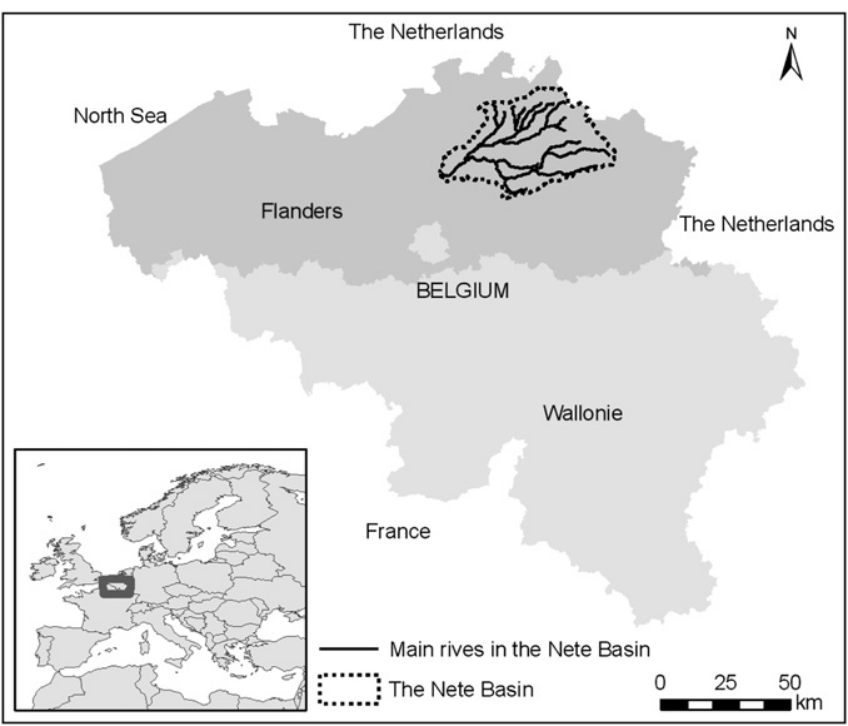

Fig. 1. Location of the Grote Nete study area in Flanders, Belgium.

\subsection{The SWAT model}

The Soil and Water Assessement Tool (SWAT) has gained international acceptance as a robust watershed modelling tool. Gassman et al. (2007) give an overview of the more than 50 peer-reviewed publications on SWAT for pollutant assessments, linked to a hydrological assessment. SWAT has proven to be effective to simulate the impact of point and non-point emission reduction measures. SWAT integrates both land phase and in-stream processes and is suited to simulate alternative land uses and best management practices (BMPs), such as fertilizer and manure application rates and timing, cover crops (perennial grasses), crop rotations, filter strips, conservation tillage, grassed waterways, and wetlands. In SWAT, point source measures are implemented as a scenario with a reduced input load which is then routed through the system. The amount of load reduction needs to be quantified with external tools. The measures used in this work are described in Section 2.4. Point source measures consist of emission load reductions from industrial and public waste water. The agricultural measures are considered to reduce non-point sources only.

The use of SWAT for impact assessment of measures on nitrogen is reported by a.o. Chaplot et al. (2004), Arabi et al. (2006), Bracmort et al. (2006), Gassman et al. (2006), Santhi et al. (2006), Tong and Naramngam (2007), Nendel (2009), Pandey et al. (2009), Sahu and Gu (2009) and Volk et al. (2009).

The presented model is set up and calibrated for the period 2002-2006 for flow, nitrogen components, phosphorus, BOD and dissolved oxygen. Only the results for flow and nitrogen are presented (Fig. 2).

In order to model the nitrogen load balance, data from different sources with different time steps and scale were collected. Point source data from industry and WWTP on discharges and emission loads are available for individual companies or

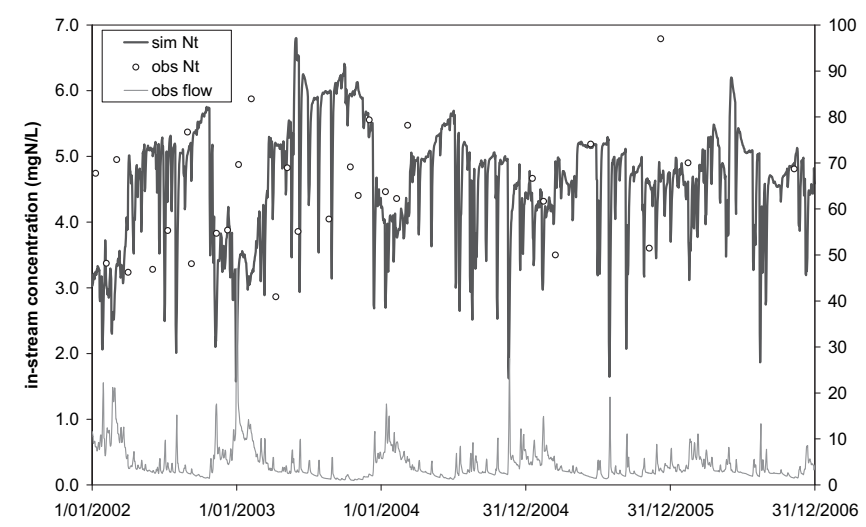

Fig. 2. Output of SWAT for total nitrogen $\left(\mathrm{mgN} \mathrm{I}^{-1}\right)$ and observations of total nitrogen and flow $\left(\mathrm{m}^{3} / \mathrm{s}\right)$. 
stations on an annual basis. In-stream water quality measurements are available at monthly basis whereas the data on emission loads of unconnected households and the mass of fertilizer applied are available on annual basis and at the scale of the municipality. The latter two emission sources, which correspond to $50 \%$ of the total emission load for nitrogen, are converted to 14 sub sub-catchments and are entered into SWAT as constant daily values.

Firstly, the SWAT model is calibrated for flow. The Nash-Sutcliff Efficiency (NSE) reached is 0.72 . A better calibration is not feasible and a systematic underestimation of summer flow is observed. Due to the overgrowth by weeds in summer, the water is backed up in a significant part of the studied catchment. Secondly, the nitrogen components are calibrated against the residual between the modelled and the observed average concentrations. This simple objective function was chosen, in view of the fact that only a limited amount of monthly in-stream water quality data was available. For total nitrogen, the average observed concentration was $4.5 \mathrm{mgNl}^{-1}$ whereas the average modelled concentration was $4.6 \mathrm{mgN}^{-1}$. For nitrate, a residual of zero was obtained: both the average modelled and observed concentration were $2.1 \mathrm{mgNl}^{-1}$.

\subsection{The environmental costing model}

The Environmental Costing Model or ECM is developed to assist policy makers in designing programs of cost-effective measures to meet the criteria for a good water status according to the WFD. The model, initially set up for industrial air pollution (Eyckmans et al., 2005; Lodewijks and Meynaerts, 2007), has been adapted to optimize the surface water quality management. Emission sources incorporated are industry, households and agriculture. Pollutants targeted are chemical oxygen demand (COD), total nitrogen $\left(\mathrm{N}_{\mathrm{t}}\right)$ and total phosphorus $\left(\mathrm{P}_{\mathrm{t}}\right)$.

The ECM, programmed in GAMS (Rosenthal, 2008), determines the least-cost combination of abatement measures by means of mixed integer programming. The following straightforward optimization algorithm is applied:

For a given pollutant, p, ECM minimizes the objective function given by the following equation:

$\operatorname{Min}\left(C+t_{\mathrm{p}} E_{\mathrm{p}}\right)$

where $C$ is the total cost of the pollution abatement measures in $€ /$ year; $E_{\mathrm{p}}$ the residual export emission load of pollutant $\mathrm{p}$ and $t_{\mathrm{p}}$ the (virtual) tax placed upon the residual export emission load.

The cost of the pollution abatement measures is calculated as

$C=\sum_{m=1}^{i} \sum_{s=1}^{n}\left[\alpha_{m, s} C_{m, s}\right]$

and the residual export emission load of pollutant $\mathrm{p}$ as

$E_{\mathrm{p}}=\sum_{m=1}^{i} \sum_{s=1}^{n}\left[E 0_{s, \mathrm{p}} \times\left(1-R_{m, \mathrm{p}}\right) \times \alpha_{m, s}\right]$

where $C_{m, s}$ is the cost to apply measure $m$ on source $s, \alpha_{m, s}$ is a binary decision variable which selects abatement measure $m$ on emission source $s, E 0_{s, p}$ is the export emission load for the reference state and $R_{m, \mathrm{p}}$ is the efficiency (in \%) of measure $m$ in reducing pollutant $\mathrm{p}$.

Hereby, the following constraints hold:

$$
\sum_{m=1}^{i} \alpha_{m, s}=1 \quad \forall s
$$

$$
\alpha_{m, s} \in[0,1] \quad \forall s, m
$$

From the equations, it can be derived that if the marginal cost of a measure is lower than the tax, the measure will be selected as the most cost-effective. If not, the virtual tax will be paid. The next cost-effective measures will be selected by iteratively increasing the tax. The latter leads to a cost-effective ranking of abatement measures. Results can then be visualized in marginal abatement cost curves. Hereby, marginal cost is defined as the ratio of the difference in cost $C$ between consecutive optimizations and the difference in abated emissions. The total cost $\mathrm{C}$ comprises both discounted investment costs and annual operational costs. The residual emission export load $E_{\mathrm{p}}$ is calculated as the sum of the export emission loads in the reference year (2006) $\left(E 0_{s, \mathrm{p}}\right)$ multiplied with the estimated reduction efficiencies $R$ of selected measures, as expressed in Eq. (3).

As the optimization algorithm aims to rank measures or a combination of measures, Eqs. (4) and (5) are added such that exactly one (combination of) measure is selected for each individual source. Hence, both the individual measure as well as each combination of measures is added as a separate measure into the database. The latter has the advantage that complementary and mutually exclusive interactions between measures can be taken into account. For example, tertiary treatment for waste water can only be selected if secondary treatment is also selected in a previous iteration step.

\subsection{Description of emission reduction measures}

The emission reduction measures listed in this paper are defined in the draft river basin management plan of the Scheldt river basin (CIW, 2008) and are considered relevant in the emission reduction of nutrients by policy makers and experts (industry, agriculture, waste water treatment). In the optimization algorithm, it is assumed that, when selected, a measure is implemented uniformly by all emission sources in the study area. A distinction between sources situated upstream and downstream is not made. Information about the measures, such as costs and reduction efficiency, is collected on an individual source level, but then summed for all sources in the basin. Although many authors, mainly in the US (e.g. Srivastava et al., 2002; Whittaker et al., 2003 and Arabi et al., 2006) have proven that a uniform collective implementation is much less cost-effective than a spatially distributed optimization, a cost optimization on individual source level is not requested by policy makers for the purpose of the RBMP.

The ECM makes a distinction between basic and supplementary measures, as defined in the WFD. Basic measures are measures necessary to comply with existing European or national water legislation or measures that are already foreseen in ongoing policy, such as the Urban Waste Water Treatment Directive (91/271/EEC) and the Nitrates Directive (91/676/EEC). Supplementary measures are implemented in addition to the basic measures in order to achieve good water status. Basic measures are to be implemented anyhow and cannot be decided upon based on a cost-effectiveness analysis as is the case for supplementary measures. Yet, it is important to include the impact of basic measures in cost-effective optimization as their expected emission reductions will affect the reduction potential of supplementary measures and thereby their cost-effectiveness. The cost of basic measures is artificially set to zero to ensure that basic measures are selected in the first iteration steps. The measures included in the optimization are given in Table 1 . The index letter is referred to in the marginal cost abatement function (Fig. 6).

The basic measures (measure 'a') include the construction or renovation of existing WWTP bigger than 2000 Inhabitant Equivalents (IE), the connection of existing sewers to new waste water collectors, the implementation of Best Available Technologies (BAT) and associated concentration targets in industrial companies and compliance with the existing nutrient legislation (Nitrative Directive).

Supplementary measures have been defined across sectors, including improvements of waste water treatment plants (WWTPs) and agricultural measures. For waste water treatment plants, the renovation or construction of smaller WWTPs $(<2000$ IE) is defined (measure 'b'). Cost estimates are available for each individual station and are based on average renovation costs of similar WWTPs. The expected efficiency gains after renovating an existing WWTP are based on the legal targets ( $80 \%$ for stations with a capacity $>4.000$ IE and $60 \%$ for stations with a capacity $<4.000 \mathrm{IE})$.

For households not connected to a WWTP, a distinction is made between households connected to a sewage system and households not connected to a sewage system. For the first group of households, the existing sewers are connected to new collectors (measure ' $c$ '). For the second group, the construction of new sewers is defined as a supplementary measure, based on the distance to existing sewage networks and thus costs to connect (measures ' $\mathrm{d} / \mathrm{e} / \mathrm{f}$ ). For the most remote houses, the construction of a small scale individual treatment plant is assessed (measure ' $g$ '). Costs are assessed for each individual sewage project, based on the available investment plans for waste water collection and the amount of sewage required to connect households.

For individual industrial companies, the starting point for defining supplementary measures are concentration targets. Based on differences between observed concentrations and targets, the required reduction potential is calculated for each company. A distinction is made between targets based on BAT (measure 'a') and more stringent concentration targets based on the targets for WWTPs in the Urban Waste water Directive (measure ' $h$ '). Once the required reduction potential for each company is calculated, waste water treatment technologies are selected to estimate the costs. Potential end-of-pipe technologies are selected depending on the observed concentration, the industrial sector and the technologies already implemented.

For agriculture a series of supplementary abatement measures are distinguished, i.e. measures aimed at reducing nutrient production by cattle, restricting nutrient application to crops and reducing nutrient loss from fields. For livestock reduction of poultry (measure ' $q$ ') and pig-cattle (measure ' $r$ '), the reduction over the period 2001-2004 is extrapolated. The yearly cost of production capacity lost is calculated using the Standard Gross Margin per animal. With measure ' $i$ ', the dairy cattle efficiency is increased through more efficient farming from the current mean of $7.156 \mathrm{~kg} / \mathrm{cow}$ year to $9000 \mathrm{~kg} / \mathrm{cow}$ year. Although the latter results in an increasing excretion per cow, a lower total amount of cattle is needed to produce the same amount of milk. Thus, total excretion on river basin scale decreases. More productive dairy cattle results in an increased income (negative cost) of $0.71 € / 100 \mathrm{l}$ milk. The nutrient excretion of pigs and poultry is decreased by better tuning the protein content of pig or poultry feed (measure n/o) to their needs in during different growth phases. These feeds are more expensive, though, and the installations necessary for phased feeding require additional investments. For the restriction of nutrient application to crops, two measures have been defined: Tuned fertilization (measure ' $m$ ') and implementing a more strict fertilization limit 
Table 1

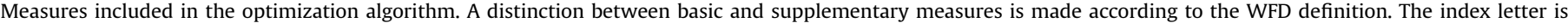
referred to in the marginal cost abatement function (Fig. 6).

\begin{tabular}{|c|c|c|c|c|}
\hline Source & Measure & index & Basic & Sup. \\
\hline \multirow[t]{2}{*}{ WWTP } & $\begin{array}{l}\text { Construction or renovation of existing WWTP }>2000 \text { IE to reach efficiency } \\
\text { targets of European Urban Waste water Directive }\end{array}$ & $\mathrm{a}$ & $\mathrm{x}$ & \\
\hline & $\begin{array}{l}\text { Construction or renovation of existing WWTP }<2000 \text { IE to reach efficiency targets } \\
\text { of European Urban Waste water Directive }\end{array}$ & $\mathrm{b}$ & & $\mathrm{x}$ \\
\hline \multirow{4}{*}{$\begin{array}{l}\text { Households (waste } \\
\text { water not treated) }\end{array}$} & Connection of existing sewers to new collectors (projects planned before or during 2006) & a & $\mathrm{x}$ & \\
\hline & Connection of existing sewers to new collectors (projects planned after 2006) & c & & $\mathrm{x}$ \\
\hline & $\begin{array}{l}\text { Extension of the sewerage network; divided in three groups according to the cost: } \\
\text { 1) smaller than cost of individual treatment (low-cost sewage), } \\
\text { 2) cost of sewerage }<2 \times \text { cost of individual treatment (medium-cost sewage), } \\
\text { 3) cost of sewerage }>2 \times \text { cost of individual treatment (high-cost sewage) }\end{array}$ & $\mathrm{d} / \mathrm{e} / \mathrm{f}$ & & $\mathrm{x}$ \\
\hline & Iindividual waste water treatment for remote houses & $\mathrm{g}$ & & $\mathrm{x}$ \\
\hline \multirow[t]{2}{*}{ Industry } & Implement Best Available Technologies (BAT) and associated concentration targets & a & $\mathrm{x}$ & \\
\hline & Implement standards of Urban Waste water Directive for industrial waste water & h & & $\mathrm{x}$ \\
\hline \multirow[t]{9}{*}{ Agriculture } & $\begin{array}{l}\text { Comply with existing nutrient legislation, including derogation of European } \\
\text { Nitrates Directive }\end{array}$ & a & $\mathrm{x}$ & \\
\hline & Increased dairy cattle productivity & $\mathrm{i}$ & & $\mathrm{x}$ \\
\hline & Winter cover crops & $\mathrm{j}$ & & $\mathrm{x}$ \\
\hline & Conservation tillage & $\mathrm{k}$ & & $\mathrm{x}$ \\
\hline & Buffer strips along watercourses & 1 & & $\mathrm{x}$ \\
\hline & Fertilization without excess (maximum up to crop requirements) & $\mathrm{m}$ & & $\mathrm{x}$ \\
\hline & Increased feed efficiency (pigs and poultry) & $\mathrm{n} / \mathrm{o}$ & & $\mathrm{x}$ \\
\hline & More strict nutrient legislation (exclusion of Nitrates Directive derogation) & $\mathrm{p}$ & & $\mathrm{x}$ \\
\hline & Livestock reduction (poultry and other livestock) & $\mathrm{q} / \mathrm{r}$ & & $\mathrm{x}$ \\
\hline
\end{tabular}

(measure 'p'). Tuned fertilization means that excess fertilization is avoided. Manure is only applied up to the crops' $\mathrm{N}$ requirements or to the legal limits and chemical fertilizer is only added if $\mathrm{N}$ needs are larger than what can legally be supplied by manure. This means a reduction of mineral $N$ with $37 \%$. Professional advice based on soil analysis can help farmers to achieve this. However, advisory costs outweigh the reduced costs of chemical fertilizer. A further reduction in animal manure application fertilizer is proposed in measure 'p'. Application rates from $250 \mathrm{~kg} \mathrm{~N} /$ ha year on grassland and $200 \mathrm{~kg} \mathrm{~N} / \mathrm{ha}$ year on maize are reduced. to $170 \mathrm{~kg} \mathrm{~N} / \mathrm{ha}$ year on all crops. Compared with the basic measure, this reduces the manure disposal area is reduced by $4 \%$ (Claeys et al., 2008) and manure export or processing needs to increase with $48 \%$ compared to the basic scenario.

A last group of agricultural measures aims to reduce nutrient losses from fields Buffer strips along watercourses (measure 'l') are estimated to reduce particle runoff from fields by 51-94\% (MESAM, 2007), but have little effect on nitrate abatement. Conservation tillage (measure ' $k$ ') reduces particle runoff by $42 \%$ (MESAM, 2007) to 93\% (Gillijns et al., 2004). The costs of reduced tillage relate to the acquirement of the appropriate machinery and production losses which can go up to $60 € /$ ha (Huybrechts, 2006). Finally, winter cover crops (measure ' $j$ ') reduce erosion and take up nutrients (especially nitrogen) that remain in the soil after the main crop is harvested. Losses can be reduced by $25-35 \mathrm{~kg} \mathrm{~N} /$ ha year (Den Boer et al., 2002). The costs are related to buying seed and cultivation. Cost savings are realized thanks to a decreased need for chemical fertilizer.

\subsection{Coupling of SWAT and ECM}

The ECM as standalone does not allow assessing whether a specific load reduction achieves a water quality standard expressed as a concentration. For this purpose, the coupling with a surface water quality model, such as SWAT, is required. SWAT also simulates the export load and in-stream processes which are missing in the ECM. A stationary coupling between SWAT and ECM is considered adequate for the long-term planning purposes considered in a river basin management plan. As shown in Fig. 3, data is exchanged between separately running models. Firstly, the ECM calculates the required load reduction of a measure following Eq. (3). Secondly, the obtained load reduction is entered in SWAT as a scenario. On its turn, SWAT models the resulting change of the in-stream concentration. Thirdly, based on multiple scenario runs, as described below, a relationship is set up between the total load reduction and the in-stream concentration. From that relationship, two parameters are derived which are sent back to the ECM. The first parameter is the required emission reduction effort to reach the concentration target. The second parameter is the sensitivity of the in-stream concentration to an emission reduction, expressed as a mass (in $\mathrm{mgN}^{-1}$ reduction/ $\mathrm{kgN}$ reduction).

As measures targeting point sources have a different sensitivity than measures targeting diffuse sources, their marginal costs cannot be compared directly. The latter however is a prerequisite for an integrated cost-effective ranking of both types of measures. In order to do so, the marginal costs of diffuse measures have been scaled to the level of point source measures by using the ratio of the sensitivity values. Hence, the optimization algorithm becomes Eq. (6):

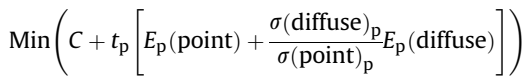

where in comparison to Eq. (1), the residual export emission load $E_{\mathrm{p}}$ is split into point and diffuse sources, $\sigma$ is added as the sensitivity of the in-stream concentration, respectively for point sources and diffuse sources.

To set up the relationship between the load reduction and the in-stream concentration, three load reduction scenarios have been applied, as shown in Table 2: 1 ) a reduction of point sources only; 2 ) a reduction of fertilizer application only and 3) a combined and equal reduction of diffuse and point sources. In all three scenarios, the emission loads of the target source have been reduced with steps of $10 \%$ of nitrogen emissions.

\section{Results and discussion}

\subsection{Impact of emission reduction on water quality}

For the three scenarios, the relationship between in-stream concentration and emission load reduction is shown in Fig. 4 for total nitrogen and in Fig. 5 for nitrate. The two horizontal lines correspond to the water quality standards for good and very good status. In order to comply with the WFD, at least the category 'good' needs to be achieved. The standards fixed for the study area in

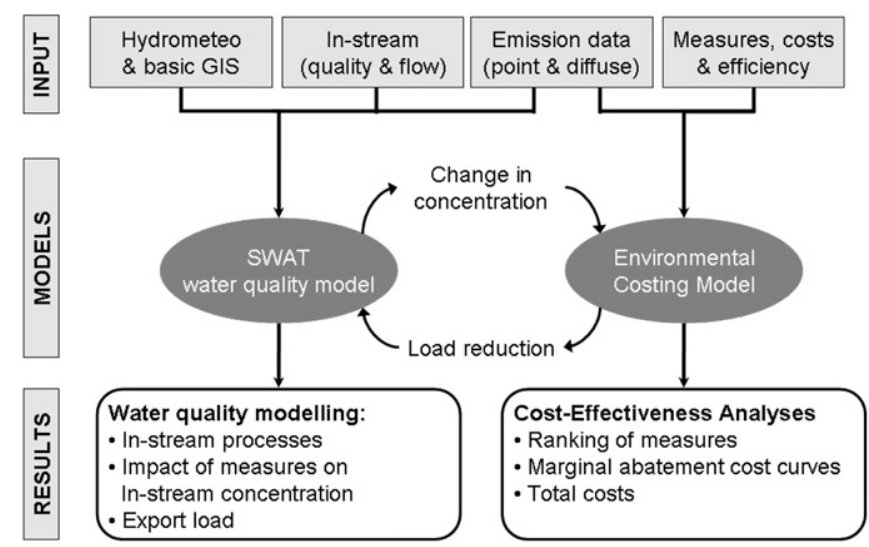

Fig. 3. Overview of the input-output and coupling between SWAT and ECM. 
Table 2

Scenarios applied for emission reductions.

\begin{tabular}{|c|c|c|c|}
\hline & Name & Point sources & Diffuse sources \\
\hline Scenario 1 & X\% POINT RED & $\begin{array}{l}\text { Reduced with } \\
\text { steps of } 10 \%\end{array}$ & 0\% Reduction \\
\hline Scenario 2 & X\% FERT RED & 0\% Reduction & $\begin{array}{l}\text { Reduced with } \\
\text { steps of } 10 \%\end{array}$ \\
\hline Scenario 3 & X\% BOTH RED & $\begin{array}{l}\text { Reduced with } \\
\text { steps of } 10 \%\end{array}$ & Reduced with steps of $10 \%$ \\
\hline
\end{tabular}

Flanders for total nitrogen and nitrate are shown in Table 3 (CIW, 2008). Note that that the standard for nitrate $\left(\mathrm{NO}_{3}^{-}\right)$is expressed as a 90 percentile whereas for total nitrogen $\left(\mathrm{N}_{\mathrm{t}}\right)$, the standard is a summer half-annual average.

The required emission reduction percentages to achieve the water quality standards for total nitrogen and nitrate can be derived from Figs. 4 and 5 and are summarized in Table 4 . Good status for total nitrogen can be achieved when: 1) point emission loads are reduced with $30 \%$; 2 ) diffuse emissions are reduced with $70 \%$ or 3 ) both point and diffuse sources are reduced by $20 \%$. To achieve the very good status, efforts need to be doubled. In that case, only reducing agricultural emissions will not be sufficient to reach the target. For nitrate, a good status is already obtained. The very good status can only be achieved when $50 \%$ of the agricultural emissions are cut or when $35 \%$ of both point source and diffuse emissions are reduced. The very good status cannot be reached by only reducing the point sources.

Based on the slopes of the relationships in Figs. 4 and 5, the sensitivity can be assessed in qualitative terms. For total nitrogen, a reduction in point sources shows the largest sensitivity whereas a reduction in agricultural sources has the largest sensitivity for nitrate. This is explained by the large fractions of organic nitrogen and ammonia in the effluent from industry, WWTP and households. For agricultural emissions, the majority of the in-stream nitrogen loads originates from the nitrate dissolved in the base flow. Peak loads of nitrogen are mainly composed of organic nitrogen. Less manure application drastically reduces the nitrate loads in the base flow, especially in summer when the contribution of base flow to total flow is maximal.

Whereas reduction targets in percentages are useful for rough planning, the sensitivity in mass units is needed in order to set up the marginal abatement cost curves. Given that a $1 \%$ reduction of the export load of total nitrogen corresponds to a $8.8 \mathrm{kgN}$ for diffuse sources and $17.5 \mathrm{kgN}$ for point sources, the following sensitivity values are found: $-0.0018 \mathrm{mgN}^{-1} / \mathrm{kgN}$ reduction of point sources and $-0.0012 \mathrm{mgN}^{-1} / \mathrm{kgN}$ reduction of fertilizer. The sensitivity for point sources is $50 \%$ higher than for diffuse sources. Yet, the

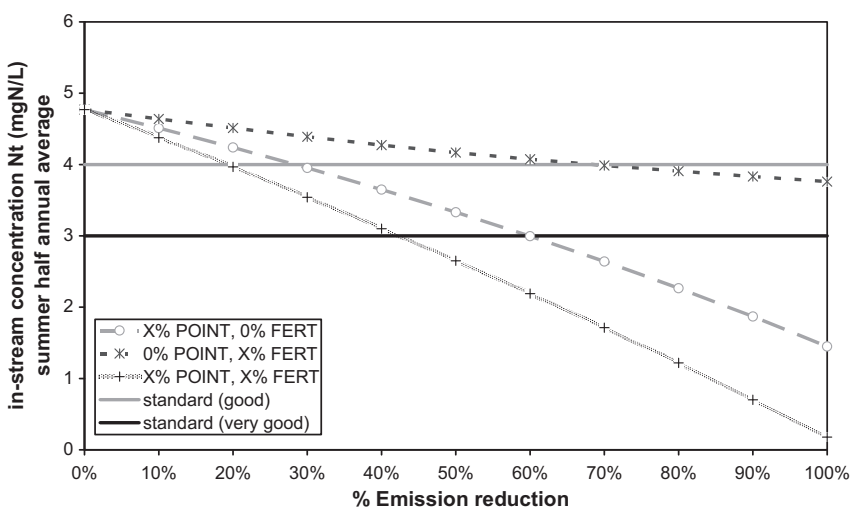

Fig. 4. Relationship between in-stream concentration and emission reduction for total nitrogen (summer half-annual averages). The horizontal lines indicate the WFD standards: $4 \mathrm{mgNl}^{-1}$ for good status and $3 \mathrm{mgNl}^{-1}$ for very good status.

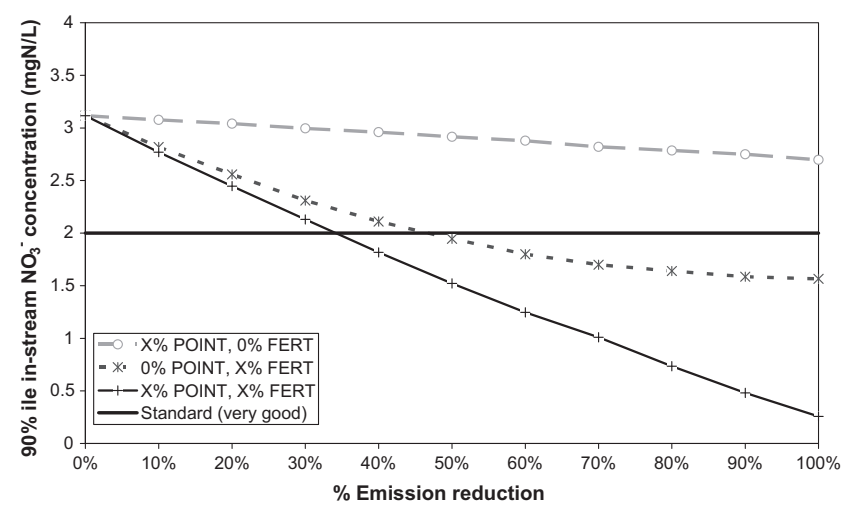

Fig. 5. Relationship between in-stream concentration and emission reduction for nitrate (90 percentile). The horizontal line indicate the WFD standards for very good status $\left(2 \mathrm{mgNl}^{-1}\right)$. The good status is already reached.

sensitivity for diffuse sources is based on the export load. When compared to the applied fertilizer, the sensitivity of the in-stream concentration for total nitrogen to a $\mathrm{kgN}$ reduction is an order of magnitude lower as it needs to be multiplied by the export load coefficient. Modelling results in SWAT showed that the export load coefficients for each sub basin range between $4 \%$ and $17 \%$ with an average of $8.6 \%$. The variability can be explained through differences in the distance to the outlet, the degree of excess manure and the availability of (natural) organic matter in addition to the applied nutrients (Table 5).

Although the nitrogen pathways and processes considered in SWAT are non-linear, model results shows that the relationship between in-stream concentrations to reductions in point and diffuse sources can be approximated as linear for summer halfannual averages of total nitrogen and 90 percentile values of nitrate (up to $30 \%$ emission reduction). For nitrate, a saturation effect is observed for diffuse sources at about an emission reduction of more than $30 \%$. The latter is considered to be the new short term equilibrium. Soil-groundwater exchange processes for nitrogen however remain to exist. The full benefits of reduced fertilizer application are only expected on the longer term (10-20 years).

For the study area, the linear relationship is valid for impact assessment of nitrogen abatement in the modelled range of concentrations. Linearization of the prevailing non-linear processes is acceptable given the specific conditions of the study area. Firstly, in-stream conversions of nitrogen components are small as the travel time is less than one day. Secondly, as the discharge is dominated by base flow, the majority of the diffuse export load is dissolved as nitrate into the groundwater. Groundwater processes in SWAT can be considered as being linear due to the semi-lumped approach. Similar results using SWAT or variants are obtained by Chaplot et al. (2004) and Jha et al. (2007) for the intensively manured lowlands of Iowa (US).

\subsection{Marginal abatement cost curves}

The coupled SWAT-ECM model provides the marginal costs of measures. Potential supplementary measures are ranked in order of

Table 3

Flemish interpretation of WFD standards for total nitrogen and nitrate (CIW, 2008).

\begin{tabular}{lll}
\hline Class & $\mathrm{NO}_{3}^{-}\left(\mathrm{mgNl}^{-1}\right)$ & $\mathrm{N}_{\mathrm{t}}\left(\mathrm{mgN}^{-1}\right)$ \\
\hline Calculation method & 90 percentile & $\begin{array}{l}\text { Summer half-annual } \\
\text { average }\end{array}$ \\
Very good & $\leq 2$ & $\leq 3$ \\
Good & $2-10$ & $3-4$ \\
\hline
\end{tabular}


Table 4

Required emission reduction percentages to achieve the WFD standards. "NO" means the standard cannot be achieved.

\begin{tabular}{|c|c|c|c|c|c|}
\hline \multirow[t]{2}{*}{ Scenario } & \multirow[t]{2}{*}{ Name } & \multicolumn{2}{|c|}{ Total nitrogen } & \multicolumn{2}{|l|}{ Nitrate } \\
\hline & & $\begin{array}{l}\text { Good } \\
\text { status }\end{array}$ & $\begin{array}{l}\text { Very good } \\
\text { status }\end{array}$ & $\begin{array}{l}\text { Good } \\
\text { status }\end{array}$ & $\begin{array}{l}\text { Very good } \\
\text { status }\end{array}$ \\
\hline $\begin{array}{c}\text { Scenario } \\
1\end{array}$ & $\begin{array}{l}\text { X\% POINT } \\
\text { RED }\end{array}$ & $30 \%$ & $60 \%$ & $0 \%$ & NO \\
\hline $\begin{array}{c}\text { Scenario } \\
2\end{array}$ & X\% FERT RED & $70 \%$ & NO & $0 \%$ & $50 \%$ \\
\hline $\begin{array}{c}\text { Scenario } \\
3\end{array}$ & $\begin{array}{l}\text { X\% BOTH } \\
\text { RED }\end{array}$ & $20 \%$ & $40 \%$ & $0 \%$ & $35 \%$ \\
\hline
\end{tabular}

decreasing cost-effectiveness and consequently plotted as shown in Fig. 6 for total nitrogen in function of the associated in-stream concentration into stepwise marginal abatement cost curves integrating both point and diffuse sources and measures across sectors. Hereby, it is assumed that decision-makers will take the most costeffective measure first and will only invest in additional measures if the required target is not met. The latter explains the stepwise shape of the abatement cost curve. The height of each step corresponds to the marginal cost of an additional reduction measure. The length of a step corresponds to the concentration reduction capacity. The vertical gray line indicates the in-stream average concentration target. The letters refer to the measures listed in Table 1.

Good status ( $4 \mathrm{mgN}^{-1}$ ) for total nitrogen can be reached in the Grote Nete catchment after implementing the following measures: more productive dairy cattle (measure "i" in Fig. 6), implementing basic measures as defined in the WFD (a), winter cover crops $(j)$, improved WWTP efficiency (b), enhanced fodder efficiency for pigs $(\mathrm{n})$, further treatment of industrial waste water (h) and tuned fertilization $(\mathrm{m})$. The good status for total nitrogen can be reached at a marginal cost of 53 Euro $/ \mathrm{kgN}$ removed. The very good status $\left(3 \mathrm{mgN}^{-1}\right.$ ) cannot be reached even if all remaining, less cost-efficient measures are selected. The cumulative emission reduction of all measures included in the assessment corresponds to an emission reduction of total nitrogen of $38 \%$ spread over diffuse and point sources.

The less cost-efficient measures are lowering the maximal rates for manure application to the level of the EU Nitrates Directive, including the processing of excess manure $(p)$, reducing the amount of poultry (q), extending the local sewage networks grouped into cheap (d), moderate (e) and expensive (f), extending regional sanitation infrastructure (c), reducing cattle and pigs (r), increasing fodder efficiency for other livestock (o) and individual treatment for household waste water $(\mathrm{g})$. It was assessed that implementing buffer strips along watercourses (l) and reduced tillage (k) would have no additional impact on total nitrogen. These measures are not presented in the figure below.

The presented results are based on average estimates for both costs and effects. The ranking of measures might change when minimum or maximum estimates are applied. Although we have not performed an uncertainty analysis, we consider that, the difference in cost-effectiveness between the most cost-effective measures (i, a, j, b) and the other measures is so large that a potential change in ranking among the most effective measures

Table 5

Sensitivity of in-stream concentration to an emission reduction for total nitrogen (in $\mathrm{mgN}^{-1} / \mathrm{kgN}$ reduction).

\begin{tabular}{lll}
\hline Scenario & Name & $\begin{array}{l}\text { Sensitivity of total nitrogen } \\
\text { (in } \mathrm{mgN}^{-1} / \mathrm{kgN} \text { reduction) }\end{array}$ \\
\hline Scenario 1 & X\% POINT RED & -0.0018 \\
Scenario 2 & X\% FERT RED & -0.0012 \\
Scenario 3 & X\% BOTH RED & -0.0017 \\
\hline
\end{tabular}

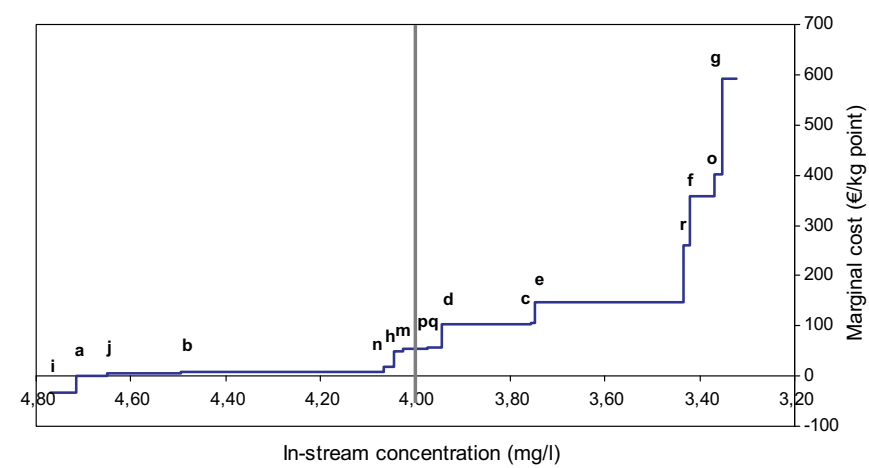

Fig. 6. Marginal cost abatement function for total nitrogen. The vertical gray line indicates the 'good status' standard. The letters refer to measures targeting both point and diffuse sources as listed in Table 1 .

does not alter the selection of these measures. The same conclusion is valid for the least cost-effective measures (c, e, r, f, o, g). Even at the extreme case when minimum cost estimates and maximum effectiveness estimates are applied, these measures will not be selected as cost-effective measures. A third group of measures, the moderately cost-effective measures ( $n, h, m, p, q, d$ ), however have a cost-effectiveness that is more or less equal and some of these measures are required to reach the objective. Based on the cost effectiveness analysis and the uncertainty related to costs and effects, we cannot conclude which of these measures need to be selected to reach the objectives at the lowest cost achievable. Besides cost effectiveness other criteria as the efforts and capacity needed to get and keep a measure going and stakeholder acceptance certainly play a role when choosing between these measures.

\section{Summary and conclusions}

A hydro-economic modelling framework is presented to set up a cost-effective program of measures to achieve an in-stream concentration target. It consists of a modular coupling between the hydrological water quality model SWAT and the economic optimization model ECM. As in most hydro-economic modelling work (Harou et al., 2009), the hydrological processes have been simplified. A semi-linear relationship has been setup, after a series of simulations in SWAT, between point and diffuse emission load reductions and $90 \%$ ile water quality concentrations. This relation is then integrated in the ECM to determine the measures required to achieve water quality targets by means of a marginal abatement cost curve. The latter is considered to be a valid first assessment 1) to quantify the required emission reduction to reach an in-stream concentration target and 2) to compare the cost-effectiveness of measures across sectors and processes on the scale of a river basin.

Results show that the good status for total nitrogen can be reached in the study area. The most cost-effective measures are more productive dairy cattle, implementing basic measures as defined in the WFD, winter cover crops, improved efficiency of WWTP, enhanced fodder efficiency for pigs, further treatment of industrial waste water and tuned fertilization. An approach aiming at an emission reduction from all sectors is the most cost-effective program of measures to improve the in-stream water quality. The biggest reduction of total nitrogen can be obtained through a reduction of point sources. However, when focusing on nitrate, relevant e.g. for the Nitrate Directive or Groundwater Directive, targeting agricultural sources has the biggest impact. The large variation in marginal costs shows a large potential for cost savings if a cost-effective selection is performed. A cost-effectiveness analysis provides an added value for river basin management in specific, and for natural resources management and biodiversity 
conservation in general since the costs and impacts of proposed measures are made explicit. As the results are prone to uncertainty and more accurate cost-effectiveness analyses are expected in the next planning cycles of the WFD, the results should not be accepted as the optimal program of measures, but as a transparent basis for negotiation between stakeholders and authorities.

\section{Acknowledgements}

The authors acknowledge the Flemish Environment Administration (LNE) and the Flemish Environment Agency (VMM) who commissioned the studies on which this paper is based.

\section{References}

Arabi, M., Govindaraju, R.S., Hantush, M.M., 2006. Cost-effective allocation of watershed management practices using a genetic algorithm. Water Resources Research 42, W10429. doi:10.1029/2006WR004931.

Attwood, J.D., McCarl, B., Chen, C.C., Eddleman, B.R., Nayda, B., Srinivasan, R., 2000. Assessing regional impacts of change: linking economic and environmental models. Agricultural Systems 63 (3), 147-159.

Balmford, A., Bruner, A., Cooper, P., et al., 2002. Economic reasons for conserving wild nature. Science 297, 950-953.

Bracmort, K.S., Arabi, M., Frankenberger, J.R., Engel, B.A., Arnold, J.G., 2006. Modeling long-term water quality impact of structural BMPs. Transactions of the ASABE 49 (2), 367-374.

Broekx, S., Meynaerts, E., Vercaemst, P., 2008. ‘Finaal Rapport Milieukostenmodel Water voor Vlaanderen - Berekeningen voor het stroomgebiedbeheerplan 2009'. Studie uitgevoerd in opdracht van het Vlaams Gewest, VITO NV, 2008.

Brouwer, R., De Blois, C., 2008. Integrated modelling of risk and uncertainty underlying the cost and effectiveness of water quality measures. Environmental Modelling \& Software 23, 922-937.

Brouwer, R., Hofkes, M., 2008. Integrated hydro-economic modelling: approaches, key issues and future research directions. Ecological Economics 66, 16-22.

Chaplot, V., Saleh, A., Jaynes, D.B., Arnold, J., 2004. Predicting water, sediment and NO3-N loads under scenarios of land-use and management practices in a flat watershed. Water. Air and Soil Pollution 154, 271-293.

CIW, 2008. Ontwerp Stroomgebiedsbeheerplan voor de Schelde. Coordinatiecommissie Integraal Waterbeleid [in Dutch: draft management plan for the river basin district of the Scheldt river]. Available at: www.volvanwater.be (last visited August, 13, 2009).

Claeys, D., Lauwers, L., Marchand, F., Vander Vennet, B., Van Meensel, J., Buysse, J., Van der Straeten, B., Van Huylebroeck, G, 2008. Modular data and mode management for multi-user's purposes: case of manure allocation, disposal and abatement. In: 107th EAAE Seminar 'Modelling Agricultural and Rural Development Policies', Sevilla, Spain.

Costanza, R., d'Arge, R., de Groot, R., Farber, S., Grasso, M., Hannon, B., Limburg, K., Naeem, S., O’Neill, R.V., Paruelo, J., Raskin, R.G., Sutton, P., van den Belt, M., 15 May 1997. The value of the world's ecosystem services and natural capital. Nature 387.

Daily, G.C., Polasky, S., Goldstein, J., Kareiva, P.M., Mooney, H.A., Pejchar, L., Ricketts, T.H., Salzman, J., Shallenberger, R., 2009. Ecosystem services in decision-making: time to deliver. Frontiers in Ecology and the Environment 7 (1), 21-28. doi:10.1890/080025.

Den Boer, D., Bakker, R., Vergeer, W., 2002. Minder verliezen door betere benutting. Bemesting 'Koeien \& Kansen' 1999-2001. Koeien \& Kansen Rapport 13. Nutriënten Management Instituut, Wageningen. http://www. verantwoordeveehouderij.nl, $68 \mathrm{pp}$.

Drechsler, M., Grimm, V., Mysiak, J., Wätzold, F., 2007. Differences and similarities between ecological and economic models for biodiversity conservation. Ecological Economics 62 (2), 232-241.

Eyckmans, J., Meynaerts, E., Ochelen, S., mei 2005. The Environmental Costing Model: a tool for more efficient environmental policymaking in Flanders. The ICFAI Journal of Environmental Economics III (nummer 2).

Fröschl, L., Pierrard, R., Schönbäck, W., 2008. Cost-efficient choice of measures in agriculture to reduce the nitrogen load flowing from the Danube river into the Black Sea. Ecological Economics 68, 96-105.

Gascuel-Odoux, C., Aurousseau, P., Cordier, M.-O., Durand, P., Garcia, F., Masson, V. Salmon-Monviola, J., Tortrat, F., Trepos, R., 2009. A decision-oriented model to evaluate the effect of land use and agricultural management on herbicide contamination in stream water. Environmental Modelling \& Software 24 (12), 1433-1446.

Gassman, P.W., Osei, E., Saleh, A., Hauck, L.M., 2002. Application of an environmental and economic modeling system for watershed assessments. Journal of the American Water Resources Association 38 (2), 423-438.

Gassman, P.W., Osei, E., Saleh, A., Rodecap, J., Norvell, S., Williams, J., 2006. Alternative practices for sediment and nutrient loss control on livestock farms in northeast Iowa. Agriculture, Ecosystems and Environment 117 (2-3), 135-144.
Gassman, P.W., Reyes, M., Green, C.H., Arnold, J.G., 2007. The soil and water assessment tool: historical development, applications, and future directions. Transactions of the ASABE 50 (4), 1211-1250.

Gillijns, K., Govers, G., Poesen, J., Van Hecke, E., Verbist, K., Gabriels D., 2004. Reductie van sedimentaanvoer naar waterlopen vanuit landelijke gebieden: begroting en evaluatie van controlemaatregelen. Minimale bodembewerking en grasbufferstroken.

Hattermann, F.F., Kundzewicz, Z.W., 2010. Water Framework Directive: Model Supported Implementation: A Water Manager's Guide. IWA Publishing.

Harou, J.J., Pulido-Velazquez, M., Rosenberg, D.E., Medellin-Azuara, J., Lund, J.R. Howit, R.E., 2009. Hydro-economic models: concepts, design, applications, and future prospects. Journal of Hydrology 375, 627-643.

Holvoet, K., van Griensven, A., Gevaert, V., Seuntjens, P., Vanrolleghem, P.A., 2008 Modifications to the SWAT code for modelling direct pesticide losses. Environmental Modelling \& Software 23 (1), 72-81.

Huybrechts, M., 2006. Kosten-batenanalyse van erosiebestrijdingsmaatregelen [Costbenefit analysis of erosion prevention measures]. In: Presentation at the Closing Symposium of the Interreg IIIa Project Erosiebestrijding, Alden Biezen, Bilzen.

Interwies, E., Borchardt, D., Kraemer, A., Kranz, N., Görlach, B., Richter, S., Willecke, J., Dworak, T., 2004. Basic principles for selecting the most cost-effective combinations of measures for inclusion in the programme of measures as described in Article 11 of the Water Framework Directive.

Jha, M.K., Gassman, P.W., Arnold, J.G., 2007. Water quality modeling for the Raccoon River Watershed using SWAT. Transactions of the ASABE. ISSN: 0001-2351 50 (2). ISSN: 0001-2351, 479-493.

Lodewijks, P., Meynaerts, E., 2007. The Environmental Costing Model: a tool to advise policy makers in Flanders on issues of cost efficiency. In: Proceeding of the 6th International Conference on Urban Air Quality, Cyprus, 27-29 March 2007.

Lise, W., Van der Veeren, R.J.H.M., 2002. Cost-effective nutrient emission reductionsin the Rhine river basin. Integrated Assessment 3 (4), 321. and 342.

MESAM, 2007. Project 'Measures against Erosion and Sensibilisation of fArmers for the protection of the environMent', Interreg IIIa project border region NorthFrance and South-West-Belgium, www.mesam.be.

Mysiak, J., Giupponi, C., Rosato, P., 2005. Towards the development of a decision support system for water resource management. Environmental Modelling \& Software 20 (2), 203-214.

Nelson, E., Mendoza, G., Regetz, J., Polasky, S., Tallis, H., Cameron, D.R., Chan, K.M.A., Daily, G.C., Goldstein, J., Kareiva, P.M., Lonsdorf, E., Naidoo, R., Ricketts, T.H. Shaw, M.R., 2009. Modelling multiple ecosystem services, biodiversity conservation, commodity production, and tradeoffs at landscape scales. Frontiers in Ecology and the Environment 7 (1), 4-11. doi:10.1890/080023.

Neitsch, S.L., Arnold, J.G., Kiniry, J.R., Williams, J.R., 2005. Soil and Water Assessment Tool, Theoretical Documentation, Version 2005. Blackland Research Center/Soil andWater Research Laboratory, Agricultural Research Service, Grassland/Temple, TX.

Nendel, C., 2009. Evaluation of Best Management Practices for $\mathrm{N}$ fertilisation in regional field vegetable production with a small-scale simulation model. European Journal of Agronomy 30, 110-118.

van Noordwijk, M., Tomich, T.P., Verbist, B., 2001. Negotiation support models for integrated natural resource management in tropical forest margins. Conservation Ecology 5 (2), 21.

Pandey, V.K., Panda, S.N., Pandey, A., Sudhakar, S., 2009. Evaluation of effective management plan for an agricultural watershed using AVSWAT model, remote sensing and GIS. Environmental Geology 56, 993-1008.

Qiu, Z., 2005. Using multi-criteria decision models to assess the economic and environmental impacts of farming decisions in an agricultural watershed. Review of Agricultural Economics 27 (2), 229-244.

Rosenthal, R.A., 2008. GAMS A User's Guide. GAMS Development Corporation, Washington DC, USA

Sahu, M., Gu, R.R., 2009. Modeling the effects of riparian buffer zone and contour strips on stream water quality. Ecological Engineering 35, 1167-1177.

Santhi, C., Srinivasan, R., Arnold, J.G., Williams, J.R., 2006. A modeling approach to evaluate the impacts of water quality management plans implemented in a watershed in Texas. Environmental Modelling \& Software 21 (8), 1141-1157.

Schleich, J., White, D. 1997. Cost minimization of nutrient reduction in watershed management using linear programming. Journal of the American Water Resources Association 33, 135-142.

Schlüter, M., Savitsky, A.G., McKinney, D.C., Lieth, H., 2005. Optimizing long-term water allocation in the Amudarya River delta: a water management model for ecological impact assessment. Environmental Modelling \& Software 20 (5), 529-545.

Srivastava, P., Hamlett, J.M., Robillard, P.D., Day, R.L., 2002. Watershed optimization of best management practices using AnnAGNPS and a genetic algorithm. Water Resources Research 38 (3), 1021. doi:10.1029/2001WR000365.

Tong, S.T.Y., Naramngam, S., 2007. Modeling the impacts of farming practices on water quality in the little Miami River Basin. Environmental Management 39, $853-866$.

Turpin, N., Bontems, P., Rotillon, G., Barlund, I., Kaljonen, M., Tattari, S., Feichtinger, F., Strauss, P., Haverkamp, R., Garnier, M., Lo Porto, A., Benigni, G., Leone, A., Nicoletta Ripa, M., Eklo, O.M., Romstad, E., Bioteau, T., Birgand, F. Bordenave, P., Laplana, R., Lescot, J.M., Piet, L., Zahm, F., 2005. AgriBMPWater: systems approach to environmentally acceptable farming. Environmental Modelling \& Software 20 (2), 187-196.

Tskhay, A., Zhevnov, D., Bauwens, W., Cools, J., 2005. Methodic of choice for water protection activity investment in river basin. Water Economy of Russia 7 (5), 464-481. 
Volk, M., Hirschfeld, J., Dehnhardt, A., Schmidt, G., Bohn, C., Liersch, S., Gassman, P.W., 2008. Integrated ecological-economic modelling of water pollution abatement management options in the Upper Ems River Basin. Ecological Economics 66 (1), 66-76.

Volk, M., Liersch, S., Schmidt, G., 2009. Towards the implementation of the EuropeanWater Framework Directive? Lessons learned from water quality simulations in an agricultural watershed. Land Use Policy 26, 580-588.
WATECO, 2002. Economics and the Environment. The Implementation Challenge of the Water Framework Directive. A Guidance Document. European Commission Common Implementation Strategy, Brussels.

Whittaker, G., Färe, R., Srinivasan, R., Scott, D.W., 2003. Spatial evaluation of alternative nonpoint nutrient regulatory instruments. Water Resources Research 39 (4), 1079. doi:10.1029/2001WR001119. 